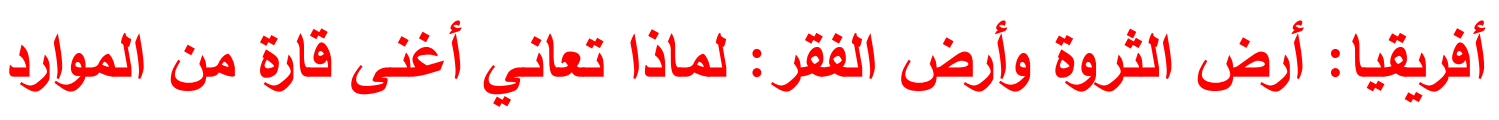
من الفقر

\title{
Africa: A Land of Wealth and a Land of Poverty: Why the Richest Resource Continent Suffers from Poverty.
}

د.أحمد صبري أبو زيل -أستاذ بكلية السياسة والاقتصاد

د.إيمان علي محفوظ سمدرس بجامعة السويس.

\section{Abstract:}

The African continent is no doubt the most resource-abundant continent Almost every country in Africa has a deposit of natural resources.Despite the abundance of resources, Africa is also the poorest continent in the world. Per capita income in African countries is among the lowest in the world. Large populations in Africa still suffer from acute poverty. Life expectancy is the lowest in Africa compared to other continents. The continent also lags in other indicators of economic growth and development. The fight against poverty hasn't been too successful in the continent.The continent has also been a recipient of foreign aid from developed country governments and international organizations. Generally, there is controversy about how beneficial foreign aid is to AfricaThe goal of this paper, therefore, is to test the presence or otherwise of the natural resource curse in Africa. The paper will also determine the effect of foreign aid on economic growth and also explore some transmission mechanisms 
associated with these relationships. This will aid in unraveling the dilemma of growth and underdevelopment in Africa.

Keywords :Africa, the natural resource curse, poverty

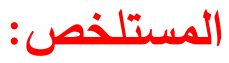

لا شك أن القارة الأفريقية هي القارة الأكثر وفرة بالموارد ، فكل بلد في إفريقيا تقريبًا لديه ودائع من الموارد الطبيعية ، وعلى الرغم من وفرة الموارد ، فإن إفريقيا هي أيضًا أفقر قارة في العالم. دخل الفرد في

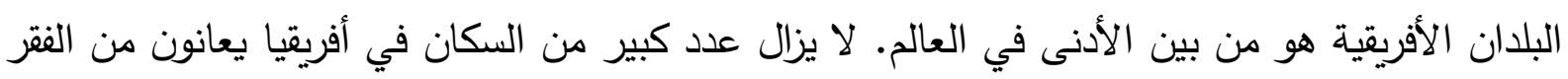

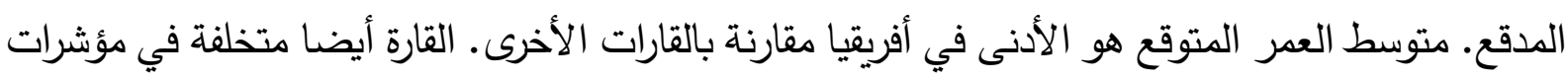

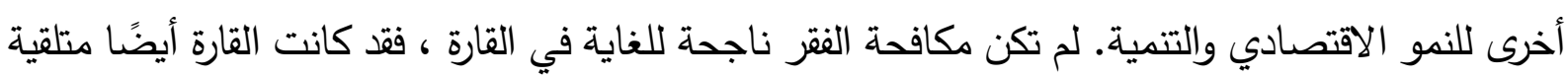
للمساعدات الخارجية من حكومات البلدان المتقدمة والمنظمات الدولية. بشكل عام ، هناك جدل حول مدى لهى فائدة المساعدات الخارجية لأفريقيا ، وبالتالي ، فإن الهدف من هذه الورقة هو اختبار وجود أو عدم وجود لعنة الموارد الطبيعية في أفريقيا. ستحدد الورقة أيضًا تأثير المساعدة الخارجية على النمو الاقتصادي وستستكشف أيضًا بعض آليات التحويل المرتبطة بهذه العلاقات. وهذا سيساعد في حل معضلة النمو والتخلف في إفريقيا .

الكلمات الافتتاحية :افريقيا ، لعنة الموارد الطبيعية ، الفقر

\section{1-Introduction}

The African continent is no doubt the most resource-abundant continent. Resources such as gold, diamond, oil, natural gas, copper, uranium, among others are mined in different parts of the continent. Almost every country in Africa has a deposit of natural resources. The continent is endowed with about $97 \%$ of the world's chromium, $90 \%$ of the world's cobalt, $85 \%$ of the word's platinum, $70 \%$ of the world's cocoa, and $60 \%$ of the world's coffee. Despite the abundance of resources, Africa is also the poorest continent in the world. Per 
capita income in African countries is among the lowest in the world. According to the World Bank, Africa has the lowest GDP per capita with its per capita income representing only $3 \%$ of the word's income. Large populations in Africa still suffer from acute poverty. Life expectancy is the lowest in Africa compared to other continents. The continent also lags in other indicators of economic growth and development. The fight against poverty hasn't been too successful in the continent. This is evidenced by the failure to meet the Millenium Development Goals (MDGs).

With such abundance in natural resources, Africa also lags in international trade. The continent controls only about $3 \%$ of international trade. This is despite the huge natural resource exports out of Africa. The continent has also recorded the most unstable democracies in the world. Political conflicts are prevalent in some African countries. Some African countries such as Somalia have even been described as failed states because of the breakdown of their government systems. These and many other factors drag African countries further down the poverty line. This presents the biggest paradox of all; the richest resource continent has the poorest countries on the earth.

Theories such as the dependency theory highlight the disadvantaged position of developing countries with natural resource abundance in the world system. Much of the underdevelopment of countries such as African countries have been blamed on excessive dependence on the western world. Capitalism has led to an unequal and exploitative international relationship between developed and developing countries, causing developed countries to dominate the developing countries. This has fueled the underdevelopment of most 
developing countries (Ghosh, 2019). Other authors blame the underdevelopment of Africa to colonialism and its attendant exploitation (Mizuno \& Okazawa, 2009a). Corruption and bad leadership have also been blamed for the lack of development of African countries. Other factors such as poor institutions and cross border conflicts have also been blamed for the underdevelopment of Africa, even in the face of natural resource abundance. This phenomenon in Africa is a reflection of what is mostly called the natural resource curse or the paradox of plenty.

The continent has also been a recipient of foreign aid from developed country governments and international organizations. Generally, there is controversy about how beneficial foreign aid is to Africa. According to a report by Conscience (2014), Africa receives about $\$ 133.7$ billion each year from official aid, grants, loans to the private sector, remittances, etc. however, at the same time, some $\$ 191.9$ billion is extracted from the continent in the form of debt repayments, multinational company profits, illicit financial flows, brain drain, illegal logging, and fishing, etc. Therefore, Africa suffers a net loss of about $\$ 85$ billion. Hence most authors often argue that the notion that the West is aiding Africa is wrong. They argue that it is Africa that is aiding the west.

The goal of this paper, therefore, is to test the presence or otherwise of the natural resource curse in Africa. The paper will also determine the effect of foreign aid on economic growth and also explore some transmission mechanisms associated with these relationships. This will aid in unraveling the dilemma of growth and underdevelopment in Africa. 


\section{2-Literature Review}

\subsection{Theories of Underdevelopment.}

Theorization of underdevelopment starts with the Rostow's modernization theory of 1960. This theory establishes the state of underdevelopment as an original state for every economy. This is generally referred to as a traditional society. However, these traditional societies undergo modernization as they progress through the various stages of development until they become modernized states. The theory defines 5 major stages of the growth and transformation of an economy. The first stage is the traditional society which is characterized by underdevelopment. The economy then moves to a stage of preconditions for takeoff as it accumulates the needed capital. The economy then takes off into development and industrialization. This stage is characterized by rapid industrialization and economic growth. The society also undergoes significant modernization. The economy then moves to the stage of the drive to maturity and eventually to the state of high mass consumption Rostow (1971)

This theory implies that every country starts from the original state of underdevelopment before it undergoes a structural transformation the sets it on a path to growth and development (Emeh, 2013). Inequalities in development among countries simply imply that countries are at different stages in the development paradigm.

The dependency theory is opposed to the view of the modernization theory. This theory was propounded by Andre Gunder Frank in 1966. This theory sees the world as divided into wealthy nations and poor nations. Other authors refer to rich countries as the core and the poor countries as the periphery 
The theory posits that the poor countries are mostly dominated by rich countries. This establishes an exploitative relationship between poor and rich countries. Poor countries provide natural resources and cheap labor without benefiting much from the system. The benefits from the system largely accrue to the rich countries as these resources flow from the poor countries to the rich countries. This situation further enriches the rich countries and impoverishes the poor countries. Hence the gap between the rich and poor countries is further widened (Emeh, 2013). Dependency is seen as a situation whereby external factors significantly influence on domestic policies. This influence transcends dimensions such as economic, political, and cultural. This dependency is what generates dominance and divides the countries into dominant and periphery countries. Hence, underdevelopment is mainly blamed on external factors. The relationship predicted by the dependency theory tends to reinforce itself, making poor countries poorer and rich countries richer.

Cockcroft et al. (1972) argue that the dependency theory makes sense only within the framework of a capitalist system. Under the capitalist system, resources will flow from the periphery or satellite countries to the metropolises or the core countries. The underdeveloped countries have therefore remained underdeveloped as a result of being dominated by capitalist economies.

Mizuno \& Okazawa (2009) also link the underdevelopment of Africa to colonialism. They argue that the indirect rule adopted by the colonial masters led to the division of the indigenous people into a privileged ruling group and the unprivileged ruled group. They argue that this system creates avenues for the colonial masters to exploit the ruled through the ruling group. This situation has 
left a history of division and distrust among the indigenous people which is not conducive for development.

Nunn (2007) blames the underdevelopment on the extractive nature of the colonial rule in Africa. A multiple equilibria model is developed; One equilibrium is with secure property rights and high production, and a lower equilibrium with insecure property rights and low production. The paper argues that extraction by external forces can cause a country that is at a high equilibrium point to fall to a low equilibrium point. Because of stability at any equilibrium, such a country can be trapped at the low equilibrium point for long. The argument, therefore, is that the extractive nature of colonialism and slave trade has pushed African countries to a low equilibrium point, and they have been largely stuck in that low equilibrium for long.

\subsection{The Natural Resource Curse}

The paradox of plenty, otherwise called a resource curse as become more apparent in Africa. For decades, it has generally been observed that countries that are rich in resources such as oil, diamonds, gold, and other minerals have not necessarily witnessed significant gains in economic growth and poverty reduction. Most African countries such as Nigeria, Congo, Niger, Ghana, etc have huge deposits of natural resources, yet economic growth in these countries is very limited and poverty and inequality are still very prevalent in these countries. Ironically, countries that are not so natural resource-rich such as Japan and Singapore have experienced tremendous growth and poverty reduction. This generally is the idea of the paradox of plenty or the resource curse hypothesis (Frankel, 2010). 
Before the 1980 s, the most commonly held view was that countries that were rich in natural resources would experience significant growth. This view can be traced back to Adams Smith and David Ricardo. They posited that natural resources were a significant factor that enhances the economic development of countries as they undergo structural change over time. The Rostow stages of growth theory further establish the important role of natural resources in the economic transformation of an economy. However, the emergence of the Dutch disease in the 1980s cast significant doubt on the widely held belief that natural resource endowment generally led to economic development (Badeeb et al., 2017). The findings of Gelb (1988) which came to be known as the Dutch disease show that oil-rich economies experienced a significant decline in the efficiency of their domestic capital compared to non-oil economies. Hence, the discovery of oil leads to slower economic growth. This finding can be expanded to cover many other natural resources. The evidence of this resource curse in Africa is telling.

The economic explanation for this phenomenon is the deindustrialization of other sectors due to the discovery and concentration of efforts in the extraction of a resource once it is discovered. A simple example of the resource curse is a popular Dutch disease. With an economy that starts from a full-employment point, a discovery of oil suddenly leads to an increase in the inflow of external funds as countries try to extract the oil. However, this inflow changes the relative prices in favor of nontraded goods such as construction and services, while affecting non-oil traded goods such as manufacturing and agriculture. Hence, non-oil traded goods are crowded out of the market. Hence, in general, the 
market for nontradables expand and this generally appreciates the currency and further affects export competitiveness. This affects output and then employment, which then translates into poverty (Di John, 2010). Essentially, such countries experience deindustrialization in sectors such as manufacturing and agriculture. These sectors have historically been known to be growth-enhancing. Hence, a decline in such sectors affects the development of the country.

Hausmann \& Rigobon (2003) offer an alternative explanation to the resource curse by linking resource income volatilities to financial market imperfections. They argue that the extent of price volatility generated from increased demand for non-tradable goods is small if the country has a large non-resource tradable sector. This is because the shock will cause labor movement reallocations between the sectors to eliminate the instabilities. However, if the non-resource tradable sector is significantly small, shocks to the demand for non-tradable goods that arise due to shocks in resource income will lead to expenditure-switching which causes relative price movements. They also argue that interest rates become dependent on price volatilities due to bankruptcy fears. These effects lead to inefficient specialization towards nontradable goods and away from non-resource tradable goods. This situation further fuels price volatility. Since this kind of specialization is inefficient, it reduces social welfare.

Another explanation for this resource curse phenomenon is the fact the world prices of natural resources such as minerals and other agricultural resources are highly volatile. Hence when countries become heavily dependent on exports of these resources, their economies are vulnerable to world price 
shocks that affect the prices of these resources. (Frankel, 2010). Any form of volatilities that cause unanticipated output growth has been identified by Van der Ploeg \& Poelhekke (2009) as one of the major reasons for the natural resource curse. They argue that market volatilities caused by natural resource growth have a negative impact on economic which exceeds the positive impacts of natural resource growth on economic growth.

Under-developed financial markets have also been identified as the possible mechanisms through which natural resources can slow the growth of economies. Bhattacharyya \& Hodler (2014) argue that natural resource revenues hinder financial development. They present a politico-economy model that links natural resource revenues to financial development through political institutions. Weak political institutions lead to poor contract enforcements which lead to poor financial sector development. They make the case that natural resource-rich countries such as most African countries have poor institutions. Hence, their financial markets are not well developed even in the presence of increased natural resource revenues. An underdeveloped financial market slows economic growth and development.

The quality of institutions in resource-rich countries has mostly been identified as the major hindrance to their development. Most of these countries are beset with corruption and rent-seeking activities which greatly hinder the proper mobilization of resource revenues. The rational-agency perspective argues that the abundance of natural resources generally leads to poor collective decision making by governments due to rents that accrue to them. These rents 
lead governments into making politically and economically inefficient decisions that hamper growth and development (Stevens \& Dietsche, 2008).

Caselli \& Cunningham (2009) focus on leader behavior as the key to determining the effect of resource abundance. They argue that increasing resource rents generally decreases total value added in the economy and hence slows growth. Increased resource revenues could induce leaders to make investments such as infrastructural investments that support other sectors of the economy. In this case, resource revenue will enhance economic growth. However, if these resource revenues and their accompanying rents induce the leader to invest in staying in power or maximizing his survival function, the results will be catastrophic as resources are diverted from development-oriented projects. Hence, political instability and leader behavior are the major hindrances to development in resource-rich African countries. Ojo (2016) blames the underdevelopment of Africa on the African leaders. He argues that irresponsible and irresponsive leaders, coupled with corruption, lack of respect for democratic ideals, insecurity, and civil wars are to blame for the underdevelopment of Africa. Awojobi, (2014) also blames Africa's underdevelopment on corruption and calls for stringent policies to combat corruption in Africa. Murshed (2004) also emphasizes intersectoral linkages as a key determinant of the resource curse. The political superstructure of these economies plays a significant role in ensuring proper intersectoral linkages. They argue that natural resource endowments retard democratic development which in turn impedes economic development. 
Othe authors such as North (1990) and Eggertsson et al (1990) also identify the role of strong institutions in economic development. Papyrakis \& Gerlagh (2004) conduct an empirical study into the transmission mechanisms through which natural resources affect growth. With data covering about 39 countries, they find that natural resources impact economic growth indirectly through corruption, which proxies for institutional quality. They show that natural resources increase corruption which in turn negatively affects economic growth. Their findings are in line with the argument of Sachs \& Warner (1995). They provide evidence of a negative relationship between natural resource endowment and economic growth. They found that countries that had relatively high ratios of natural resources to GDP in 1971, experienced slower growth during subsequent periods. This result held even after controlling for other determinants of economic growth. They argue that increased rent-seeking and corruption, state-led development agendas, and higher prices for non-traded goods are the main transmission mechanisms. Atkinson \& Hamilton (2003) also emphasizes that the resource curse may be as a result of the failure of governments of these countries to manage the large resource revenues sustainably.

Torvik (2002) develops a model that identifies rent-seeking behavior resulting from natural resource abundance as causing inefficient specialization of economic agents. They argue that natural resource abundance increases rent-seeking activities. More entrepreneurs are engaged in rent-seeking compared to those engaged in productive economic activities. The overall effect is a reduction in output and economic growth. In line with this, Mehlum et al. 
(2006) establish that poor institutions are the main problems of most resourcerich countries, especially in Africa. They argue that when institutions are grabber friendly rather than producer friendly, natural resource abundance will limit economic growth opportunities. The drop in incomes from the effect of grabber friendly institutions outweighs the increase in incomes resulting from natural resources. The overall effect of this is a reduction in welfare.

Auty \& Gelb (2001) state that natural resource-abundance economies tend to undermine investment efficiency while resource-poor economies place more premium on efficiency. As a result, resource-poor countries industrialize faster, while resource-rich economies compete for rents generated from these resources. This generates predatory states that distribute rents in ways that distort the economy.

Again it is argued that most countries that are resource-rich are normally prone to conflicts which greatly hamper the growth and development of these countries (Bannon \& Collier, 2003). Sala-i-Martin \& Subramanian (2013) also highlight the role of corruption in the dutch disease of Nigeria. They propose that to address the resource curse, oil revenues should be directly distributed to the public. This they argue is a better solution compared to the status quo where the state manages the oil revenues. This is due to the obvious corruption at state institutions. Venables (2016) argues that utilizing natural resource endowments is a multistaged economic and political problem. It involves private investments to discover and extract, good fiscal regimes that will mobilize the revenues, prudent spending and investment decisions, and effective policies to mitigate impacts of volatility and other adverse impacts on other sectors of the 
economy. Economies that do not have any of these systems properly organized are going to face obvious difficulties in harnessing the benefits of resource endowments. African countries have obvious problems with these systems and this is an obvious explanation for their inability to harness the benefits of naturalresource endowments.

\subsection{Foreign Aid and Economic Growth in Africa.}

Africa has been a recipient of foreign aid for decades now. The continent receives aid from developed country governments, multinational companies, and international organizations. The OECD reports that in 2017, net official development assistance to Africa was about $\$ 52800$ million. ODA disbursements in Africa saw a 3.9\% increase in 2017. While there is a large pool of literature that finds that foreign aid enhances economic growth and poverty reduction, other authors argue that Africa's growth prospects have been significantly limited by the flow of foreign aid into the continent.

Levy (1988) studies aid and economic growth in sub-Saharan Africa. His results confirm that foreign aid is positively related to economic growth in the region. This finding is supported by Juselius et al. (2014). They study the longrun effect of ODAs on macroeconomic variables for a sample of 36 African countries. They find evidence of a positive effect of foreign aid on economic growth. Adams \& Atsu, (2014) also find similar results for Ghana, in their study on aid dependence and economic growth. Qayyum \& Haider (2012) also finds that for low-income countries, foreign aid is positively related to economic growth. Younsi et al (2019) study the relationship between foreign aid and income inequality for a panel of 16 African countries. They find that foreign aid 
significantly reduces income inequality. The common argument these authors put forward is that foreign aid provides additional resources to support government budgetary needs and also fuels significant infrastructural developments in developing countries. Alvi \& Senbeta (2012) study the effect of foreign aid on poverty for sub-Saharan Africa. They also find that foreign aid significantly reduces poverty as measured by the poverty gap and the poverty rate. They also argue that multilateral aid does a better job at reducing poverty than bilateral aid.

Other authors however believe that reliance on foreign aid fuels corruption and inefficiency in developing countries. As a result, foreign aid generally slows economic growth and poverty reduction. Mm (2016) finds a negative effect of foreign aid on economic for Tanzania by applying a dynamic ordinary least square model to a dataset ranging from 1976 to 2014. Asongu \& Nnanna (2018) also study the long and short-run impact of foreign aid on economic growth for a sample of 53 African countries. They find that in the short-run, foreign aid has a positive effect on economic growth. However, in the long-run, foreign aid hurts economic growth. Mlambo et al. (2019) also argue that economic growth does not appear to be increasing significantly in response to increased foreign aid flows into sub-Saharan Africa. They further argue that foreign aid has worsened corruption and inefficiency in the region. Asongu (2012) also finds evidence to support the assertion that foreign aid fuels corruption in Africa. Ijaiya \& ljaiya (2004) also do not find any significant effect of foreign aid on poverty reduction in SSA. They argue that weak economic management evidenced by corruption and bad governance in most of these countries is to blame for this situation. 
Asongu \& Nwachukwu (2017) differentiate between different types of foreign aid and their effects on economic growth for a sample of 53 African countries. They find that foreign aid in areas such as social infrastructure, economic infrastructure, the productive sector, and multisector have a positive effect on economic growth. Humanitarian aid, however, has a negative effect on economic growth.

\section{3-Empirical Methodology}

\subsection{Natural Resources and Economic Growth.}

To begin the analysis we specify a model to determine the effect of natural resources on the economic wellbeing of African countries. The general form of the model is specified as:

\section{Gdpcap}

$=f($ govexp, inv, humancap, res, trade, fdi, faid, govern, L. govern)

Where Gdpcap is GDP per capita, govexp is government expenditure as a percentage of GDP, inv is domestic investment as a percentage of GDP, humancap represents human capital measured by school enrolment, res represents the natural resources, trade represents trade openness, $f d i$ represents foreign direct investments as a percentage of GDP, faid is foreign aid, govern represents an overall measure of governance, and L.govern is the one year lag of overall governance.

Six different iterations of this model are estimated. The first model is estimated with government expenditure, investment, human capital, resources, and overall governance as independent variables. Subsequent models are 
estimated with additional variables and the last model captures all the independent variables. The models are specified as:

$$
\begin{aligned}
& \text { Gdpcap }_{i t}=\beta_{0}+\beta_{1} \text { govexp }_{i t}+\beta_{2} \text { inv }_{i t}+\beta_{3} \text { humancap }_{i t}+ \\
& \beta_{4} \text { res }_{i t}+\beta_{5} \text { govern }_{i t}+\gamma_{i}+\delta_{t}+\varepsilon_{i t} \\
& \text { Gdpcap }_{i t}=\beta_{0}+\beta_{1} \text { govexp }_{i t}+\beta_{2} \text { inv }_{i t}+\beta_{3} \text { humancap }_{i t}+\beta_{4} \text { res }_{i t} \\
& +\beta_{5} \text { govern }_{i t}+\beta_{6} \text { L.govern }_{i t}+\gamma_{i}+\delta_{t}+\varepsilon_{i t} \\
& \text { Gdpcap }_{i t}=\beta_{0}+\beta_{1} \text { govexp }_{i t}+\beta_{2} \text { inv }_{i t}+\beta_{3} \text { humancap }_{i t}+\beta_{4} \text { res }_{i t} \\
& +\beta_{5} \text { govern }_{i t}+\beta_{6} f d i_{i t}+\gamma_{i}+\delta_{t}+\varepsilon_{i t} \\
& \text { Gdpcap }_{i t}=\beta_{0}+\beta_{1} \text { govexp }_{i t}+\beta_{2} \text { inv }_{i t}+\beta_{3} \text { humancap }_{i t}+\beta_{4} \text { res }_{i t} \\
& +\beta_{5} \text { govern }_{i t}+\beta_{6} \text { top }_{i t}+\gamma_{i}+\delta_{t}+\varepsilon_{i t} \\
& \text { Gdpcap }_{i t}=\beta_{0}+\beta_{1} \text { govexp }_{i t}+\beta_{2} \text { inv }_{i t}+\beta_{3} \text { humancap }_{i t}+\beta_{4} \text { res }_{i t} \\
& +\beta_{5} \text { govern }_{i t}+\beta_{6} \text { faid }_{i t}+\gamma_{i}+\delta_{t}+\varepsilon_{i t} \\
& \text { Gdpcap }_{i t}=\beta_{0}+\beta_{1} \text { govexp }_{i t}+\beta_{2} \text { inv }_{i t}+\beta_{3} \text { humancap }_{i t}+\beta_{4} \text { res }_{i t} \\
& +\beta_{5} \text { govern }_{i t}+\beta_{6} f d i_{i t}+\beta_{7} \text { top }_{i t}+\beta_{7} \text { faid }_{i t}+\gamma_{i} \\
& +\delta_{t}+\varepsilon_{i t}
\end{aligned}
$$

All variables are as previously defined. it represents the country and time dimensions, $\gamma_{i}$ represents the country fixed effects, $\delta_{t}$ represents the year fixed effects, and $\varepsilon_{i t}$ represents the random error term. The countries in the sample are grouped based on income levels into three groups namely; low-income 
countries, lower-middle-income countries, and upper-middle-income countries. All 6 models above are estimated for each of the income groupings.

To estimate these models, fixed-effects and random-effects estimation techniques are adopted. Since the data is a panel data, country-specific heterogeneities become an important point of consideration in estimating the models. The use of ordinary least squares in the presence of country-specific heterogeneities will lead to biased estimates. This is because the least-squares regression ignores these heterogeneities altogether and treats all countries as similar.

The fixed-effects model is used when the country-specific time-invariant fixed effects exist and are correlated with the predictor variables. These effects are however unique and not correlated with each other (Torres-Reyna, 2007). The fixed-effects model transforms the model to eliminate the country-specific fixed effects. The random-effects model is used when the country-specific fixed effects are purely random and uncorrelated with the independent variables. The important distinction between fixed and random effects is whether the countryspecific characteristics contain elements that can be correlated with the predictor variables (Green, 2008, p. 183)

Since the difference between the two models is the relationship between the country-fixed effects and the regressors, the Hausman test is conducted to determine if these country-fixed effects are correlated with the regressors. The null hypothesis is that random-effects is preferred. A rejection of the null hypothesis leads to the adoption of the fixed-effects model. 


\subsection{Natural Resources, Poverty, and Human Development.}

The next step in the analysis is to determine the effect of natural resources on poverty and human development. A model is first estimated to determine the impact of natural resources on poverty. This model is specified as:

$$
\begin{aligned}
\text { povhead }_{i t} & =\beta_{0}+\beta_{1} \text { gdpcap }_{i t}+\beta_{2} \text { gcf }_{i t}+\beta_{3} \text { hexp }_{i t}+\beta_{4} \text { res }_{i t} \\
& +\beta_{5} \text { popgr }_{i t}+\beta_{6} \text { fdi }_{i t}+\beta_{7} \text { top }_{i t}+\beta_{8} \text { inf }_{i t} \\
& +\beta_{9} \text { res } * \text { corruptcr }_{i t}+\beta_{10} \text { res } * \text { pstab }_{i t} \\
& +\beta_{11} \text { res } * \text { top }_{i t}+\beta_{12} \text { res } * \text { gdp } \\
& +\beta_{13} \text { conflict }_{i}+\gamma_{i} \\
& +\delta_{t}+\varepsilon_{i t}
\end{aligned}
$$

Where povhead $_{i t}$ represent the poverty headcount ratio, gdpcap $_{i t}$ is GDP per capita, $g c f_{i t}$ represents gross capital formation, hexp $p_{i t}$ represents health expenditure, popgr $_{i t}$ is the population growth rate, inf $f_{i t}$ is the inflation rate, res $*$ corruptcr $_{i t}$ represents the interaction term of natural resources with the control of corruption, res $* p_{s t a b}$ it represents the interaction term of natural resources with political stability, res $*$ top $_{i t}$ represents the interaction term of natural resources with trade openness, res $* g d p_{i t}$ represents the interaction term of natural resources with GDP, and conflict $_{i}$ is a dummy variable for the presence of conflicts. Other variables and parameters are as previously defined.

To broaden the scope of the analysis, model 7 is re-estimated with much broader measures of human development. The goal here is to determine how natural resources affect human development in general. This model is specified below: 


$$
\begin{aligned}
y_{j i t}=\beta_{0}+ & \beta_{1} \text { gdpcap }_{i t}+\beta_{2} \text { gcf }_{i t}+\beta_{3} \text { hexp }_{i t}+\beta_{4} \text { res }_{i t} \\
& +\beta_{5} \text { popgr }_{i t}+\beta_{6} \text { fdi }_{i t}+\beta_{7} \text { top }_{i t}+\beta_{8} \text { inf }_{i t} \\
& +\beta_{9} \text { res } * \text { corruptcr }_{i t}+\beta_{10} \text { res } * \text { pstab }_{i t} \\
& +\beta_{11} \text { res } * \text { top }_{i t}+\beta_{12} \text { res } * \text { gdp } \\
& +\beta_{13} \text { conflict }_{i}+\gamma_{i} \\
& +\delta_{t}+\varepsilon_{i t}
\end{aligned}
$$

Where $y_{j i t}$ represents the indicators of human development namely; life expectancy, school enrolment, and infant mortality rate. The models in this section are also estimated by fixed-effects and random-effects techniques with the use of the Hausman test to choose between the two models.

\subsection{Foreign Aid and Economic Growth.}

In this section, we analyze the role of foreign aid on economic growth. The African continent has been a recipient of foreign aid in diverse forms from countries and multinational organizations. The effect of foreign aid on the growth prospects of African countries has however been greatly questioned over the years. The model is specified as:

$$
\begin{aligned}
\text { gdpgrwth } & =\beta_{0}+\beta_{1} \text { popgr }_{i t}+\beta_{2} \text { inv }_{-} g d p_{i t}+\beta_{3} \text { faid }_{i t} \\
& +\beta_{4} \text { faid }^{2}{ }_{i t}+\beta_{5} \text { Gdp_ini }_{i t}+\beta_{6} i n f_{i t}+\gamma_{i}+\delta_{t}+\varepsilon_{i t}
\end{aligned}
$$

Where gdpgrwth is the GDP growth rate, popgr $_{i t}$ is the population growth rate, $i n v_{-} g d p_{i t}$ represents investment as a percentage of GDP. faid $d_{i t}$ is foreign aid and faid $^{2}{ }_{i t}$ is its squared term. Gdp_ini ${ }_{i t}$ is the initial level of GDP, and $i n f_{i t}$ is the inflation rate. Other parameters are as previously defined. This model is again run separately for the three income groups. 
To trace the transmission mechanisms, interactive terms of foreign aid with natural resources and governance are added to the model. Other interactions will also be added to further study the transmission channels.

\section{$\underline{4-E s t i m a t i o n ~ R e s u l t s ~ a n d ~ I n t e r p r e t a t i o n ~}$}

\subsection{Natural Resources and Economic Growth}

Table 1 presents the results of the underlying model for low-income countries. From model one, government expenditure is found to positively affect GDP per capita though not statistically significant. Investment positively affects GDP per capita. A percentage point increase in investment results in about 0.0035 point increase in GDP per capita, other variables held constant. Human capital also has a significant positive effect on GDP per capita. The results show that GDP per capita increases by about 0.00095 points in response to a oneunit increase in human capital. Natural resources have a positive but insignificant effect on GDP per capita. The overall governance index also has a significant positive effect on GDP per capita. On average, a one-unit increase in the governance index increases GDP per capita by about 0.164 units, other variables held constant. Model two includes a lag value of the overall governance index. Investment and human capital still have significant positive effects on GDP per capita. The coefficient of natural resources is still positive. It is now statistically significant at $10 \%$.

Table 1: Low-Income Countries: Model is based on the Random Effect Cluster method and $R$ squared within 


\section{$\begin{array}{llllll}\text { Model } 1 & \text { Model } 2 & \text { Model } 3 & \text { Model } 4 & \text { Model } 5 & \text { Model } 6\end{array}$}

Government Expenditure

$\begin{array}{cccccc}0.000103 & 0.000219 & - & 0.00107 & 0.00131 & 0.000122 \\ & & 0.0000756 & & \\ (0.00554) & (0.00477) & (0.00567) & (0.00565) & (0.00576) & (0.00581)\end{array}$

Investment

$\begin{array}{llllll}0.00351^{*} & 0.00348^{* *} & 0.00278 & 0.00383^{* *} & 0.00350^{* *} & 0.00306 \\ (0.00179) & (0.00166) & (0.00189) & (0.00176) & (0.00177) & (0.00183)\end{array}$

Human Capital

$$
\begin{array}{llllll}
0.00095^{* * *} & 0.00025^{* * *} & 0.00011^{* * *} & 0.00019^{* * *} & 0.00011^{* * *} & 0.00041^{* * *} \\
(0.00153) & (0.00142) & (0.00147) & (0.00173) & (0.00161) & (0.00172)
\end{array}
$$

Resources

$\begin{array}{rrrrrr}0.00309 & 0.00036^{*} & 0.00272 & 0.00184 & 0.00246 & 0.000765 \\ (0.00279) & (0.00224) & (0.00306) & (0.00390) & (0.00409) & (0.00539)\end{array}$

FDI

$$
\begin{array}{r}
0.00155 \\
(0.00171)
\end{array}
$$$$
0.00174
$$

Trade Openness

$-0.000499$

0.000549

$(0.000597)$

$(0.000512$

$\begin{array}{ll}0.00005 & 0.00005 \\ (0.0411) & (0.0445)\end{array}$

Foreign Aid
$0.164^{\circ \cdots "}$
$0.177^{* * *}$
$0.161^{* * *}$
$0.168^{* * *}$
$0.175^{* *}$
(0.0528)
$(0.0540)$
(0.0523)
(0.0557)
(0.0575)

One- Year Lag Overall

$0.145^{* * *}$

Governance

(0.0554) 


$\begin{array}{ccccccc}\mathbf{R}^{2} & 0.619 & 0.589 & 0.632 & 0.623 & 0.620 & 0.638 \\ \text { Chi2 } & 100.9^{\cdots \cdots} & 86.07^{\cdots *} & 108.2^{\ldots * *} & 99.16^{\ldots *} & 92.06^{\cdots *} & 91.86^{\cdots *}\end{array}$

The one-year lag of overall governance is found to positively affect GDP per capita. A unit increase in the one-year lag of overall governance results in about 0.145 units increase in GDP per capita, other variables held constant. This suggests a dynamic relationship between governance and economic growth. Model three adds foreign direct investment to model one. Only human capital and overall governance are found to be significant. The coefficient for human capital reduces to 0.00011 while that of overall governance increases to 0.177. Foreign direct investment has a positive but insignificant effect on GDP per capita. Model four adds trade openness to model one. Trade openness has a negative but insignificant effect on GDP per capita. The coefficient for investment is slightly bigger and is still statistically significant. Human capital is also statistically significant but the coefficient is much smaller. Overall governance is still positive and statistically significant. Model five adds foreign aid to the variables in model one. The coefficient of investment is still positive and statistically significant.

Human capital also maintains a positive and significant coefficient. The coefficient is however smaller. The overall governance index also maintains a positive and significant relationship. The coefficient is slightly larger. The rest of the coefficients are not statistically significant.

Model six includes all the covariates. The coefficient of government expenditure is still positive and not significant. The coefficient for investment is also positive but slightly smaller. The coefficient is significant at a ten percent 
level. Human capital is still positive and statistically significant but the coefficient is smaller. Natural resources, foreign aid, and foreign direct investment have positive and insignificant coefficients. Trade openness has a negative and insignificant coefficient. The overall governance index is still found to increase GDP per capita significantly.

The results suggest that for low-income countries, natural resources play no significant role in economic growth. This is due the fact that these countries choose to give the exploration and investment rights to foreign companies, which mostly cares about exploiting these resources regardless of the national interest of these countries. On the other hand, investment, human capital, and good governance have the strongest influence on economic growth for low-income countries. Results also indicates a negative relation between economic growth and openness, which is mainly due a huge trade deficits in this group of countries.

Table 2: Lower Middle-Income Countries: Model is based on Fixed Effect Cluster method and $\mathbf{R}$ squared within

$\begin{array}{llllll}\text { Model } 1 & \text { Model } 2 & \text { Model } 3 & \text { Model } 4 & \text { Model } 5 & \text { Model } 6\end{array}$

$\begin{array}{lllllll}\text { Government } & 0.00468 & 0.00352 & 0.00458 & 0.00553 & 0.00414 & 0.00441\end{array}$

Expenditure
$(0.00376)$
$(0.00315)$
$(0.00379)$
(0.00351)
(0.00425)
(0.00405)

Investment
0.00748 ***
0.00691 ***

$0.00735^{* * * *}$

$0.00849 * * *$

$0.00766 * * *$

$0.00877^{* * * *}$

(0.00212)

(0.00180)

(0.00215)

(0.00238)

(0.00222)

(0.00262) 


\begin{tabular}{|c|c|c|c|c|c|c|}
\hline Human & $0.00077^{* * * * *}$ & $0.00014 * * *$ & 0.00076 **** & $0.00047 * * * *$ & $0.00075^{* * * *}$ & $0.00058^{* * * *}$ \\
\hline Capital & & & & & & \\
\hline & (0.00128) & $(0.00115)$ & $(0.00127)$ & $(0.00136)$ & $(0.00132)$ & $(0.00138)$ \\
\hline Resources & 0.00221 & $0.00019^{*}$ & 0.00216 & 0.00272 & 0.00224 & 0.00277 \\
\hline & $(0.00362)$ & (0.0003) & $(0.00366)$ & $(0.00275)$ & $(0.00374)$ & $(0.00293)$ \\
\hline FDI & & & 0.00133 & & & 0.00207 \\
\hline & & & $(0.00224)$ & & & $(0.00219)$ \\
\hline Trade & & & & -0.00149 & & $-0.00166^{*}$ \\
\hline Openness & & & & & & \\
\hline & & & & $(0.000986)$ & & $(0.000975)$ \\
\hline Foreign Aid & & & & & $0.000010^{*}$ & $0.000018^{*}$ \\
\hline & & & & & $(0.00001)$ & $(0.00001)$ \\
\hline Overall & $0.337 * * *$ & & 0.336 *** & $0.325^{* * * *}$ & $0.338 \% * *$ & $0.323^{* * * *}$ \\
\hline governance & & & & & & \\
\hline & $(0.0980)$ & & (0.0990) & $(0.109)$ & $(0.0970)$ & $(0.109)$ \\
\hline One- Year & & $0.308 * * *$ & & & & \\
\hline Lag Overall & & & & & & \\
\hline & & & & & & \\
\hline
\end{tabular}

(0.0826)

$\begin{array}{ccccccc}\text { R2 } & 0.577 & 0.590 & 0.578 & 0.594 & 0.579 & 0.601 \\ \text { Chi2 } & 20.49^{* * * *} & 22.50^{* * * *} & 18.37^{* * * *} & 16.97^{* * * *} & 17.49^{* * * *} & 13.12^{* * * *}\end{array}$

Table 2 presents the results for low middle-income countries.

Government expenditure still does not have any statistically significant effect on 
GDP per capita. This runs through all 6 models. Investment is again found to have a positive and statistically significant effect on GDP per capita in all six models. The coefficients are similar across all models. From model one, for example, a one-unit increase in investment results in a 0.0074 unit increase in GDP per capita, ceteris paribus. This change increases to 0.00877 in model six where all the covariates are added. Across all 6 models, human capital has a positive and statistically significant effect on GDP per capita. From model one, a unit increase in human capital results in about 0.00077 increase in GDP per capita, other variables held constant. This decreases to 0.0058 in model six where all covariates are added. Natural resources again have no significant effect on GDP per capita in all six models. The coefficient for foreign direct investment is negative and insignificant in model three and model six. Trade openness has a negative coefficient in model four and a positive coefficient in model six. Both coefficients are however not statistically significant. Foreign aid does not also have a significant effect on GDP per capita for lower-middleincome countries. Overall governance index again has a positive and statistically significant effect on GDP per capita across all models. From model one, a unit increase in overall governance increases GDP per capita by about 0.317 units, other variables held constant. In model six, the value reduces to 0.314 . The coefficient for the lagged value of overall governance added in model two is positive and statistically significant The results are essentially not different from those for low-income countries in table one.

Table 3 presents the results for upper-middle-income countries. Increased government expenditure is found to negatively affect GDP per capita 
across all 6 models. All coefficients are however not statistically significant. Investment is again found to have a positive impact on GDP per capita across all 6 models. All coefficients are statistically significant. The coefficients are significantly larger than that of the low-income countries and middle-income countries. Human capital also has a positive effect on GDP per capita. However, the coefficient is only statistically significant in model two where the lagged of overall governance is added and in model three where FDI is added.

Table 3: Upper Middle-Income Countries: Model is based on the Random Effect Cluster method and $R$ squared within

\begin{tabular}{|c|c|c|c|c|c|c|}
\hline & Model 1 & Model 2 & Model 3 & Model 4 & Model 5 & Model 6 \\
\hline \multirow{3}{*}{$\begin{array}{l}\text { Government } \\
\text { Expenditure }\end{array}$} & -0.0132 & -0.0106 & -0.0131 & -0.0132 & -0.0131 & -0.0130 \\
\hline & & & & & & \\
\hline & $(0.0118)$ & $(0.0117)$ & $(0.0117)$ & $(0.0125)$ & $(0.0117)$ & $(0.0122)$ \\
\hline \multirow[t]{2}{*}{ Investment } & 0.0137 **** & $0.0109 * * *$ & $0.0141^{* * *}$ & $0.0137 * * *$ & $0.0139 * * *$ & 0.0141 *** \\
\hline & $(0.00411)$ & $(0.00347)$ & $(0.00430)$ & $(0.00433)$ & $(0.00414)$ & $(0.00448)$ \\
\hline \multirow{2}{*}{$\begin{array}{l}\text { Human } \\
\text { Capital }\end{array}$} & 0.00066 & $0.00033^{* * *}$ & $0.00042 * *$ & 0.00066 & 0.00060 & 0.00063 \\
\hline & $(0.00232)$ & $(0.00212)$ & $(0.00229)$ & $(0.00219)$ & $(0.00222)$ & $(0.00212)$ \\
\hline \multirow[t]{2}{*}{ Resources } & 0.00283 & 0.00345 & 0.00281 & 0.00283 & 0.00285 & 0.00283 \\
\hline & $(0.00981)$ & $(0.00737)$ & $(0.0101)$ & $(0.00995)$ & $(0.0102)$ & $(0.0105)$ \\
\hline \multirow[t]{2}{*}{ FDI } & & & -0.00152 & & & -0.00107 \\
\hline & & & $(0.00319)$ & & & $(0.00343)$ \\
\hline & & & & & & \\
\hline
\end{tabular}




\begin{tabular}{|c|c|c|c|c|c|c|}
\hline \multirow[t]{2}{*}{$\begin{array}{l}\text { Trade } \\
\text { Openness }\end{array}$} & & & & $\begin{array}{l}- \\
0.00000145\end{array}$ & & 0.0000694 \\
\hline & & & & $(0.00150)$ & & $(0.00150)$ \\
\hline \multirow[t]{2}{*}{ Foreign Aid } & & & & & 0.000088 & 0.000059 \\
\hline & & & & & $(0.0398)$ & $(0.0385)$ \\
\hline \multirow{2}{*}{$\begin{array}{l}\text { Overall } \\
\text { governance }\end{array}$} & $0.317 * *$ & & $0.320 * *$ & $0.316 * *$ & $0.312^{* *}$ & $0.314^{* *}$ \\
\hline & $(0.135)$ & & $(0.137)$ & $(0.135)$ & $(0.123)$ & $(0.124)$ \\
\hline \multirow{2}{*}{$\begin{array}{l}\text { One-Year } \\
\text { lag Overall } \\
\text { governance }\end{array}$} & & $0.302 * * *$ & & & & \\
\hline & & $(0.129)$ & & & & \\
\hline \multirow[t]{2}{*}{ Constant } & $8.119 * * *$ & 8.026 *** & 8.116 *** & $8.119 * * *$ & $8.115^{* * * *}$ & $8.104 * * *$ \\
\hline & $(0.294)$ & $(0.220)$ & $(0.290)$ & $(0.309)$ & $(0.293)$ & $(0.306)$ \\
\hline $\mathbf{R 2}$ & 0.357 & 0.383 & 0.358 & 0.357 & 0.358 & 0.359 \\
\hline Chi2 & $46.18 * * *$ & $71.17 * * *$ & $46.64 * * *$ & $51.54 * * *$ & $71.35^{* * * *}$ & $77.29 * * *$ \\
\hline
\end{tabular}

Natural resources still have no significant effect on GDP per capita. Foreign direct investment, foreign aid, and trade openness also have no significant effect on GDP per capita. Overall governance is again found to positively affect GDP per capita. All coefficients are statistically significant. The coefficients are almost the same size as those of the middle-income countries. The one-year lag of overall governance still has a positive and significant effect on GDP per capita.

The results imply that natural resource availability in Africa does not affect economic growth in any significant way. This runs through all the countries 
irrespective of their income levels. This highlights the basic problem of African countries. The natural resource curse does exist in Africa. The abundant natural resources in the continent have not been supportive of economic growth. The companies involved in the extraction of these natural resources in Africa are mostly foreign multi-billion-dollar businesses. However, these countries get huge tax breaks, handouts, and subsidies from governments of African countries. These are mostly done to attract foreign investors since most African countries lack the capacity to extract their natural resources. Some countries also have to give up huge shares of the extracted resources to these companies in a bid to encourage exploration by foreign investors. These factors, coupled with corruption, conflicts, and poor institutions can be blamed for the natural resource curse in Africa.

It is also intriguing to find that trade openness does not significantly affect economic growth in Africa. This could suggest that African countries are not reaping significant benefits from opening their economies up for international trade. Foreign direct investments are also not significantly affecting the growth of African countries. These findings could be due to the nature of institutions. Weak institutions are not conducive to economic growth. We see that the quality of governance has a positive effect on economic growth. Strengthening the governance framework in Africa will create the needed environment for countries to benefit from open trade and foreign direct investments. Hence, corruption and government inefficiencies should be reduced significantly to strengthen the governance framework and make it more conducive to economic growth. 


\subsection{Poverty and Natural Resources.}

This section presents the results for the regression to determine the effects of natural resource abundance on poverty. The poverty headcount ratio is the dependent variable. As expected GDP per capita is found to significantly reduce poverty. A unit increase in GDP per capita will result in a 0.29 point reduction in poverty headcount, other variables held constant. Gross capital formation also significantly reduces poverty. A unit increase in gross capital formation reduces poverty by about 0.08 units on average, other variables held constant. Government health expenditure has a negative but insignificant effect on poverty. Natural resource abundance also significantly reduces poverty. A unit increase in natural resources reduces poverty by about 0.032 points average decrease in poverty, other variables held constant.

\section{Table 4: Poverty Headcount and Natural Resources}

\begin{tabular}{|l|l|}
\hline Independent & $\begin{array}{l}\text { Dependent: Poverty } \\
\text { Headcount }\end{array}$ \\
\hline Constant & -1.717 \\
& $(5.735)$ \\
\hline (GDP per capita) & -.293 \\
& $(.126)^{* *}$ \\
\hline Gross Capital Formation & -.080 \\
\hline Health Expenditure & $(.009) * * *$ \\
\hline Natural Resource & -.081 \\
& $(.094)$ \\
\hline
\end{tabular}




\begin{tabular}{|l|l|}
\hline & \multicolumn{1}{|c|}{$(.013)^{* * *}$} \\
\hline Population & $\begin{array}{l}.212 \\
(.107)^{*}\end{array}$ \\
\hline FDI & $\begin{array}{l}-.007 \\
(.038)\end{array}$ \\
\hline Trade Openness & -.010 \\
\hline Inflation & $(.005)^{* * *}$ \\
\hline (Natural Resource* control & -.027 \\
\hline of corruption) & $(.009) * * *$ \\
\hline (Natural Resource* political & -.037 \\
\hline stability) & $(.061)$ \\
\hline (Natural Resource* Trade & -.003 \\
\hline Openness) & $(.004)^{* * * *}$ \\
\hline (Natural Resource* GDP) & .073 \\
\hline Conflict Dummy & $(.020)^{* * * *}$ \\
\hline & .242 \\
\hline
\end{tabular}

An increase in population is found to increase poverty as expected. A unit increase in population increases poverty by about 0.212 units on average, other variables held constant. Foreign direct investment has a negative but insignificant effect on poverty. Trade openness also significantly reduces poverty. A percentage point increase in trade openness reduces poverty on 
average by 0.01 units. Inflation increases poverty as expected. A percentage point increase in inflation increases poverty by 0.027 units on average, other variables held constant.

To further determine the effects of natural resources on poverty under given conditions, interaction terms of natural resources with other variables are added to the regression. Natural resource interacted with corruption control is found to significantly reduce poverty. When corruption control measures are put in place, a unit increase in natural resources reduces poverty by about 0.486 on average, other variables held constant. This coefficient is higher than the earlier coefficient of natural resources. This means that corruption has a significant influence on the extent to which African countries can benefit from natural resources. Natural resources interacted with political stability also produces a bigger coefficient. The coefficients are however not statistically significant. Natural resources interacted with trade openness also has a significant poverty reduction effect. In the presence of trade openness, a unit increase in natural resources reduces poverty by 0.003 units on average, other variables held constant. Natural resources interacted with GDP also produces a negative coefficient. This is however statistically insignificant. A dummy variable for conflict is also added to the regression. As expected, the presence of conflict increases poverty by about 0.242 units compared to the absence of conflicts.

\subsection{Human Development Indicators and Natural Resources.}

To determine the impact of natural resource abundance on overall wellbeing, natural resources are regressed on broader measures of human 
development. Mainly, life expectancy, school enrolment, and infant mortality rates are used to measure the overall welfare of citizens. Table 5 presents the results. The results show that GDP per capita increases life expectancy and school enrolment but decreases infant mortality rate. A unit increase in GDP per capita increases life expectancy on average by 0.039 units, school enrolment by 0.026 units, and reduces the infant mortality rate by about 0.524 units on average, other variables held constant. These relationships are as expected.

\section{Table 5: HDI Indicators and Natural Resources}

\begin{tabular}{|c|c|c|c|}
\hline Independent & Life Expectancy & Schooling & IMR \\
\hline Constant & $\begin{array}{l}3.951 \\
\quad(.154)^{* * *}\end{array}$ & $\begin{array}{l}4.298 \\
\quad(.109)^{* * *}\end{array}$ & $\begin{array}{l}7.105 \\
(.419)^{* * * *}\end{array}$ \\
\hline (GDP per capita) & $\begin{array}{l}.0391 \\
(.004)^{* * * *}\end{array}$ & $\begin{array}{l}.026 \\
(.009)^{* * * *}\end{array}$ & $\begin{array}{l}-.524 \\
(.040) \text { **** * }\end{array}$ \\
\hline Gross Capital Formation & $\begin{array}{l}.082 \\
(.032)^{* *}\end{array}$ & $\begin{array}{l}.003 \\
(.001)^{* * *}\end{array}$ & $\begin{array}{l}-.003 \\
(.003)\end{array}$ \\
\hline Health Expenditure & $\begin{array}{l}.006 \\
(.003)^{* *}\end{array}$ & $\begin{array}{l}.021 \\
(.008)^{* * *}\end{array}$ & $\begin{array}{l}-.044 \\
\quad(.021)^{* * *}\end{array}$ \\
\hline Natural Resources & $\begin{array}{l}.001 \\
(.025)\end{array}$ & $\begin{array}{l}.006 \\
(.07)\end{array}$ & $\begin{array}{l}-.002 \\
(.003)\end{array}$ \\
\hline Population & $\begin{array}{l}-.004 \\
\quad(.002)^{* *}\end{array}$ & $\begin{array}{l}-.012 \\
\quad(.004)^{* *}\end{array}$ & $\begin{array}{l}.046 \\
(.024) *\end{array}$ \\
\hline FDI & $\begin{array}{r}-.002 \\
(.001)\end{array}$ & $\begin{array}{l}.005 \\
(.003)\end{array}$ & $\begin{array}{l}-.014 \\
(.011)\end{array}$ \\
\hline Trade & $\begin{array}{l}.003 \\
(.002)\end{array}$ & $\begin{array}{l}.006 \\
(.002)^{* *}\end{array}$ & $\begin{array}{l}-.122 \\
\quad(.041)^{* * * *}\end{array}$ \\
\hline Inflation & -.007 & -.001 & .036 \\
\hline
\end{tabular}




\begin{tabular}{|l|l|c|l|}
\hline & $(.006)$ & $(.14)$ & $(.029)$ \\
\hline (Natural Resource* control of & .005 & .028 & -.084 \\
\hline corruption) & $(.003) *$ & $(.008) * * *$ & $(.026) * *$ \\
\hline (Natural Resource* Political & .4009 & 1.995 & -.827 \\
\hline Stability) & $(.226) *$ & $(.8475) * *$ & $(.858)$ \\
\hline (Natural Resource* Trade & -.003 & .004 & -.002 \\
\hline Openness) & $(.003)$ & $(.005)$ & $(.027)$ \\
\hline (Natural Resource* GDP) & .003 & .005 & -.014 \\
& $(.002)$ & $(.005)$ & $(.027)$ \\
\hline Conflict Dummy & -2.16 & -2.269 & 6.233 \\
& $(.824) * * *$ & $(1.866)$ & $(3.03) * *$ \\
\hline
\end{tabular}

As expected, gross capital formation increases life expectancy and school enrolment while decreasing infant mortality. The effect on infant mortality rate is however not statistically significant. A unit increase in gross capital formation results in about 0.082 units increases in life expectancy and about 0.003 unit increase in school enrolment. Health expenditure is found to increase life expectancy and school enrolment while reducing infant mortality rate as expected. On average, a unit increase in health expenditure increases life expectancy by 0.006 units, school enrolment by 0.021 units, and reduces infant mortality by about 0.044 percentage points, other variables held constant.

Natural resources do not have any statistically significant effects on life expectancy, school enrolment, and infant mortality rate. Even though natural resources were found to reduce poverty in general, natural resources do not appear to have any significant effects on broader measures of human 
development. This is further evidence of the presence of the natural resource curse in Africa.

The population growth rate is found to reduce life expectancy and school enrolment while increasing infant mortality rate as expected. A percentage point increase in the population growth rate reduces life expectancy and school enrolment by 0.004 and 0.012 units respectively. Infant mortality is increased by 0.046 percentage points on average, in response to a one percentage point increase in the population growth rate. Foreign direct investment and inflation have no significant effects on life expectancy, school enrolment, and infant mortality rate. A percentage point increase in trade openness results in about 0.006 unit increase in school enrolment and a 0.122 percentage point reduction in infant mortality rate. The effect on life expectancy is not significant.

Again natural resource variable is interacted with other policy variables to determine how the effect of natural resources will change under given conditions. Natural resources interacted with control of corruption increases life expectancy and school enrolment and reduces the infant mortality rate. The coefficients are all statistically significant. This suggests that corruption is one of the major hindrances to African countries with respect to benefiting from natural resource abundance. Natural resources interacted with political stability also increase life expectancy and school enrolment and reduces infant mortality rate. Interacting natural resources with trade openness and GDP do not have any significant effects on human development measures.

The presence of conflict reduces life expectancy and school enrolment while increasing infant mortality rate relative to the absence of conflicts. Other 
variables held constant, the presence of conflicts reduces life expectancy by 2.16 relative to the absence of conflicts. Also, infant mortality increases by about 6.23 percentage points when there are conflicts, relative to the absence of conflicts.

\subsection{Foreign Aid and Economic Growth.}

In this section, we analyze the impact of foreign aid on economic growth. Separate regressions are estimated for low-income countries, lower-middleincome countries, and upper-middle-income countries in Africa. Table 6 presents these results. Population growth has a positive but insignificant effect across all income groups. Investment also has a positive effect on economic growth. However, some coefficients for lower-income countries is statistically significant. A percentage point increase in investment to GDP increases GDP growth rate by 8.753 percentage points on average for lower-income countries. Foreign aid has a positive effect on economic growth. However, only the coefficient for lower-middle-income countries is statistically significant. The coefficients are however extremely small and can be approximated to zero. The square of foreign is added to determine if any nonlinearities exist. The coefficient for the squared term is negative for low-income and lower-middle-income countries. This implies that even though foreign aid has a positive effect on economic growth, there is a threshold point of foreign aid after which the effects become negative. Initial GDP is found to reduce economic growth for lowerincome and lower-middle-income countries while increasing economic growth for middle-income countries. However, only the coefficient for lower-middleincome countries is significant. Inflation is found to reduce economic growth. A 
percentage point increase in inflation reduces economic growth by about 0.0004 percentage points for lower-income countries and 0.056 percentage points for lower-middle-income countries. The coefficient for upper-middle-income countries is not statistically significant.

We see from the results that foreign aid has not been very beneficial to African countries as one would expect. This lends credence to the argument that foreign aid to Africa has been detrimental to the economic growth of countries. Aid is not merely one source of financing among others. It serves to make the extraction of wealth from Africa possible. Today's neoliberal era is characterized by the commodification of nature, the privatization of public goods and services, the liberalization of markets, and the licensing of looting and environmental destruction by transnational corporations. Aid uses public funds to subsidize and encourage the implementation of neoliberal policies that have resulted in the growing impoverishment of the majority, and the obscene accumulation of wealth by national elites who are among its main beneficiaries.

Table 6: Economic Growth and Foreign Aid

\begin{tabular}{|l|l|l|l|}
\hline & $\begin{array}{l}\text { Low-Income } \\
\text { Countries }\end{array}$ & $\begin{array}{l}\text { Lower-Middle Income } \\
\text { Countries }\end{array}$ & $\begin{array}{l}\text { Upper-Middle Income } \\
\text { Countries }\end{array}$ \\
\hline Popg & 0.0359 & 0.308 & 0.259 \\
\hline & $(0.17)$ & $(0.74)$ & $(0.31)$ \\
\hline Inv_Gdp & $8.753^{* * * *}$ & 0.395 & 0.155 \\
\hline & $(7.81)$ & $(0.67)$ & $(0.36)$ \\
\hline FAid & 0.00000000352 & $0.00000000157^{* * *}$ & 0.00000000457 \\
\hline & $(0.93)$ & $(2.61)$ & $(0.43)$ \\
\hline
\end{tabular}




\begin{tabular}{|c|c|c|c|}
\hline \multirow[t]{2}{*}{$(\text { FAid })^{2}$} & $-17.88 * * *$ & $-9.661^{* *}$ & 69.63 \\
\hline & $(-7.54)$ & $(-2.32)$ & $(-1.73)$ \\
\hline \multirow[t]{2}{*}{ Gdp_Ini } & -0.0216 & $-0.187^{*}$ & 0.107 \\
\hline & $(-0.72)$ & $(-2.34)$ & $(0.15)$ \\
\hline \multirow[t]{2}{*}{ Inflation } & $-0.0004136^{*}$ & $-0.0565459^{*}$ & -0.0694722 \\
\hline & $(-1.81)$ & $(-1.93)$ & $(-0.94)$ \\
\hline \multirow[t]{2}{*}{ _Cons } & -0.414 & -0.133 & 0.321 \\
\hline & $(-0.64)$ & $(-0.14)$ & -0.18 \\
\hline $\mathbf{R}^{2}$ & 0.58 & 0.45 & 0.61 \\
\hline $\begin{array}{l}\text { z statistics } \\
\text { in } \\
\text { parentheses }\end{array}$ & & & \\
\hline
\end{tabular}

Table 7 presents the results for various transmission mechanisms. These are estimated for the full sample only. We see that natural resources interacted with foreign aid negatively affect economic growth. This implies that foreign aid to Africa is not conducive to the attempts by governments to reap the benefits of natural resources. This is finding is not surprising. Foreign aid flows to African countries will create an environment that allows developed country governments and corporations to dominate and control developing countries. This can lead to the adoption of policies related to natural resource extraction and trade that are detrimental to the growth prospects of African countries, while only benefiting developed country governments and corporations.

Table 7: Transmission Channels 


\begin{tabular}{|l|l|l|l|l|}
\hline Resources*Foreign Aid & $-0.00202^{*}$ & & & \\
\hline Governance*Resources & $(0.000158)$ & & & \\
\hline Governance*Foreign & & $\mathbf{0 . 0 0 5 3 3 *}$ & & \\
\hline Aid & & & $0.00513^{*}$ & \\
\hline & & & $(0.00300)$ & \\
\hline Education*Governance & & & $0.00137 *$ \\
\hline
\end{tabular}

Governance interacted with natural resources has a positive and statistically significant effect on economic growth. This means that good governance creates an environment that enables African countries to benefit from natural resources. Good governance, evidenced by low corruption and rent-seeking activities will ensure that appropriate measures are put in place to ensure the efficient exploration of the natural resources and the management of resource revenues in ways that will stimulate economic growth.

Good governance interacted with foreign aid also has a positive effect on economic growth. Good governance will ensure the proper utilization of resources from foreign aid which will spur economic growth. Education interacted with good governance also has a positive effect on economic growth as expected.

\section{Table 8: Governance Indicators}

\section{Voice \& Accountability $\quad 0.0876^{* * *}$}


Politic Stability

$0.0643^{* *}$

$(0.0292)$
Government Effectiveness

Regularity Quality

Rule of Law

Control of Corruption
$0.0828^{* * *}$

$(0.0260)$

0.0584

$(0.0840)$

$0.171^{* * *}$

$(0.0680)$

$0.0568^{* * *}$

$(0.0295)$

Table 8 presents the results for governance indicators. These variables are employed to emphasize the role of good governance in spurring economic growth. Good governance transcends diverse areas including accountability, rule of law, corruption control, government effectiveness, quality regulations, and political stability. The results show that voice and accountability enhance economic growth. A one-point increase in the voice and accountability index increases economic growth by about 0.088 percentage points on average, other variables held constant. Political stability also enhances economic growth. A one-point increase in the political stability index increases economic growth by about 0.064 percentage points on average. Government effectiveness also enhances economic growth. Other variables held constant, a one-point increase in the government effectiveness index leads to about 0.083 percentage point increase in economic growth. Regulatory quality has no statistically significant effect on economic growth. As expected the rule of law has a strong effect on the economic growth of African countries. Other variables held constant, a onepoint increase in the rule of law index increases economic growth by about 
0.171 percentage points on average. The control of corruption also enhances economic growth. Other variables held constant, economic growth increases by about 0.057 units on average, in response to a one-point increase in the index corruption control.

The results show clearly the important role that good governance plays in the economic growth prospects of African countries. Bad governance is a common occurrence in African countries. most countries in Africa have weak democracies that are confounded with corruption and other forms of bad governance. This is significantly hampering on development in Africa.

\section{Conclusion:}

The paper examines the phenomenon of the natural resource curse in Africa. Understanding the reason why a natural resource-rich continent like Africa is still grappling with extreme poverty, inequality, and underdevelopment is key to policymakers and researchers. The paper also examines the effect of foreign aid on economic growth in Africa. The goal here is to contribute to the debate on whether the African continent benefits significantly from the flow of aid into the continent. The following conclusions can be arrived at from the analysis;

- The natural resource curse exists in Africa. Natural resource abundance was found to have no significant effect on economic growth in Africa. Low quality of institions and governance is the major obstacle son they can benefit from their wealth. Although the results indicate that natural resources wealth can help in lowering poverty, it has no impact on people's well-being in terms of education and health care. 
- Education has no significant effect on economic growth. This calls for the need not only to restructure the educational systems in African countries, but also the labor markets, noitably for skilled labor in order to lower brain drain.

- There is interdependence between foreign aid and natural resources. Foreign aid creates avenues for exploitation of African countries by developed country governments. African countries that rely soo much on foreign aid lose control over the exploitation of their natural resources which hampers economic growth and development.

- The quality of institutions is very important in the development of Africa. Several governance indicators are found to enhance economic growth in Africa. Good governance should be encouraged. State institutions and the entire structure should be strengthened. Corruption should be controlled and accountability and rule of law should be encouraged. This will make the governance system more efficient and supportive of economic growth and development in Africa.

\section{$\underline{\text { References }}$}

- Adams, S., \& Atsu, F. (2014). Aid dependence and economic growth in Ghana. Economic Analysis and Policy, 44(2), 233-242. https://doi.org/10.1016/j.eap.2014.05.001

- Alvi, E., \& Senbeta, A. (2012). Does Foreign Aid Reduce Poverty? Journal of International Development, 24(8), 955-976. https://doi.org/10.1002/jid.1790

- Asongu, S. (2012). On the Effect of Foreign Aid on Corruption (SSRN Scholarly Paper ID 2493289). Social Science Research Network. https://doi.org/10.2139/ssrn.2493289

- Asongu, S. A., \& Nwachukwu, J. C. (2017). Foreign Aid and Inclusive Development: Updated Evidence from Africa, 2005-2012*. Social Science Quarterly, 98(1), 282-298. https://doi.org/10.1111/ssqu.12275 
- Asongu, S., \& Nnanna, J. (2018). Foreign Aid and Sustainable Inclusive Human Development in Africa (SSRN Scholarly Paper ID 3278546). Social Science Research Network. https://papers.ssrn.com/abstract $=3278546$

- Atkinson, G., \& Hamilton, K. (2003). Savings, Growth and the Resource Curse Hypothesis. World Development, 31(11), 1793-1807. https://doi.org/10.1016/j.worlddev.2003.05.001

- Auty, R. M., \& Gelb, A. H. (2001). Political economy of resource-abundant states. Resource Abundance and Economic Development, 126-44.

- Awojobi, O. N. (2014). Corruption and underdevelopment in Africa: A discourse approach. International Journal of Economics, Commerce and Management, 2(10), 1-14.

- Badeeb, R. A., Lean, H. H., \& Clark, J. (2017). The evolution of the natural resource curse thesis: A critical literature survey. Resources Policy, 51, 123-134. https://doi.org/10.1016/j.resourpol.2016.10.015

- Bannon, I., \& Collier, P. (2003). Natural Resources and Violent Conflict: Options and Actions. The World Bank. https://doi.org/10.1596/0-8213-5503-1

- Bhattacharyya, S., \& Hodler, R. (2014). Do Natural Resource Revenues Hinder Financial Development? The Role of Political Institutions. World Development, 57, 101-113. https://doi.org/10.1016/j.worlddev.2013.12.003

- Caselli, F., \& Cunningham, T. (2009). Leader behaviour and the natural resource curse. Oxford Economic Papers, 61(4), 628-650. https://doi.org/10.1093/oep/gpp023

- Cockcroft, J. D., Frank, A. G., \& Johnson, D. L. (1972). Dependence and underdevelopment: Latin America's political economy. Anchor Books.

- Conscience:Taxes for Peace not War. (n.d.). Retrieved June 21, 2020, from https://www.conscienceonline.org.uk/

- Di John, J. (2010). The 'resource curse': Theory and evidence. Elcano Newsletter, 72, 9.

- Eggertsson, T., Eggertsson, P., \& Eggertsson, T. (1990). Economic behavior and institutions: Principles of Neoinstitutional Economics. Cambridge University Press.

- Emeh, I. E. J. (2013). Dependency theory and Africa's underdevelopment: A paradigm shift from pseudo-intellectualism: The Nigerian perspective. International Journal of African and Asian Studies, 1(1), 16-128. 
- Frankel, J. A. (2010). The Natural Resource Curse: A Survey (Working Paper No. 15836; Working Paper Series). National Bureau of Economic Research. https://doi.org/10.3386/w15836

- Gelb, A. H. (1988). Oil windfalls: Blessing or curse? Oxford university press.

- Ghosh, B. N. (2019). Dependency Theory Revisited. Routledge.

- Green, W. H. (2008). Handbook of Econometrics. Applied Econometrics, 2, 413-556.

- Hausmann, R., \& Rigobon, R. (2003). An Alternative Interpretation of the "Resource Curse": Theory and Policy Implications (Working Paper No. 9424; Working Paper Series). National Bureau of Economic Research. https://doi.org/10.3386/w9424

- ljaiya, G. T., \& ljaiya, M. A. (2004). Foreign aid and poverty reduction in Sub-Saharan Africa: A cross-country investigation. South African Journal of Economic and Management Sciences, 7(3), 542-552.

- Juselius, K., Møller, N. F., \& Tarp, F. (2014). The Long-Run Impact of Foreign Aid in 36 African Countries: Insights from Multivariate Time Series Analysis*. Oxford Bulletin of Economics and Statistics, 76(2), 153-184. https://doi.org/10.1111/obes.12012

- Levy, V. (1988). Aid and growth in Sub-Saharan Africa: The recent experience. European Economic Review, 32(9), 1777-1795. https://doi.org/10.1016/0014-2921(88)90085-2

- Mehlum, H., Moene, K., \& Torvik, R. (2006). Institutions and the Resource Curse*. The Economic Journal, 116(508), 1-20. https://doi.org/10.1111/j.1468-0297.2006.01045.x

- Mizuno, N., \& Okazawa, R. (2009a). Colonial experience and postcolonial underdevelopment in Africa. Public Choice, 141(3), 405-419. https://doi.org/10.1007/s11127-009-9461-8

- Mizuno, N., \& Okazawa, R. (2009b). Colonial experience and postcolonial underdevelopment in Africa. Public Choice, 141(3), 405-419. https://doi.org/10.1007/s11127-009-9461-8

- Mlambo, V. H., Maduku, H., Mdletshe, B., Mlambo, D. N., \& Zubane, S. (2019). Rethinking foreign aid for socio-economic development in Sub-Saharan Africa. African Renaissance, 16(3), 277-294. https://doi.org/10.31920/2516-5305/2019/v16n3a14 
- Mm, A. (2016). What are the Impact of Foreign Aid to the Economic Growth? Time SeriesAnalysis with New Evidence from Tanzania. https://doi.org/10.4172/21516219.1000237

- Murshed, S. M. (2004). When Does Natural Resource Abundance Lead to a Resource Curse? (No. 1032-2016-83913). AgEcon Search. https://doi.org/10.22004/ag.econ.24137

- North, D. C. (1990). Institutions, institutional change and economic performance. Cambridge university press.

- Nunn, N. (2007). Historical legacies: A model linking Africa's past to its current underdevelopment. Journal of Development Economics, 83(1), 157-175. https://doi.org/10.1016/j.jdeveco.2005.12.003

- Ojo, E. O. (2016). Underdevelopment in Africa: Theories and facts. The Journal of Social, Political and Economic Studies, 41(1), 89-103.

- Papyrakis, E., \& Gerlagh, R. (2004). The resource curse hypothesis and its transmission channels. Journal of Comparative Economics, 32(1), 181-193.

- Qayyum, U., \& Haider, A. (2012). Foreign Aid, External Debt and Economic Growth Nexus in Low-Income Countries: The Role of Institutional Quality. The Pakistan Development Review, 51(4), 97-115. JSTOR. https://www.jstor.org/stable/23734741

- Rostow, W. W. (1971). Politics and the Stages of Growth. Cambridge University Press. https://ideas.repec.org/b/cup/cbooks/9780521096539.html

- Sachs, J. D., \& Warner, A. M. (1995). Natural resource abundance and economic growth. National Bureau of Economic Research.

- Sala-i-Martin, X., \& Subramanian, A. (2013). Addressing the Natural Resource Curse: An Illustration from Nigeria. Journal of African Economies, 22(4), 570-615. https://doi.org/10.1093/jae/ejs033

- Stevens, P., \& Dietsche, E. (2008). Resource curse: An analysis of causes, experiences and possible ways forward. Energy Policy, 36(1), 56-65.

- Torres-Reyna, O. (2007). Panel data analysis fixed and random effects using Stata (v. 4.2). Data \& Statistical Services, Priceton University. 
- Torvik, R. (2002). Natural resources, rent seeking and welfare. Journal of Development Economics, 67(2), 455-470.

- van der Ploeg, F., \& Poelhekke, S. (2009). Volatility and the natural resource curse. Oxford Economic Papers, 61(4), 727-760. https://doi.org/10.1093/oep/gpp027

- Venables, A. J. (2016). Using Natural Resources for Development: Why Has It Proven So Difficult? Journal of Economic Perspectives, 30(1), 161-184. https://doi.org/10.1257/jep.30.1.161

- Younsi, M., Khemili, H., \& Bechtini, M. (2019). Does foreign aid help alleviate income inequality? New evidence from African countries. International Journal of Social Economics, 46(4), 549-561. https://doi.org/10.1108/IJSE-06-2018-0319

$$
* * * * * * * * * * *
$$

